\title{
The application of LIDs in Savanna region for mitigation of flooded areas
}

\author{
Aplicação de LIDs na região de Cerrado para mitigação de áreas alagadas
}

\author{
Felipe de Mendonça Fileni', Maria Elisa Leite $\operatorname{Costa}^{2}$ (D) and Conceição de Maria Albuquerque Alves ${ }^{2}$ (iD \\ ${ }^{1}$ Uppsala University, Uppsala, Suécia \\ ${ }^{2}$ Universidade de Brasilia, Brasília, DF, Brasil \\ E-mails: felipef93@gmail.com (FMF),mariaelisa@unb.br (MELC), calves@unb.br(CMAA)
}

Received: November 27, 2018 - Revised: May 29, 2019 - Accepted: August 02, 2019

\begin{abstract}
The increase in runoff volume due to urban sprawl has imposed a challenge to current urban drainage systems and future projects in order to add sustainable strategies for effective flood control especially in consolidated urban areas that would require retrofitting of urban areas with additional social and economic costs. This study is aimed at evaluating alternatives of drainage solutions in a consolidated urban area in the Federal District of Brazil, located in Savanna region, based on the reduction of peak flow and flooded volume in the areas exposed to flood hazard. Different solutions based on the concepts of Low Impact Development (LID) were simulated, showing that the current traditional drainage system is not in compliance with local regulations in the Federal District. In addition, the use of permeable pavements and stormwater ponds could reduce at least $46 \%$ of the flooded volume. When placed along with the drainage network, not only at the outlet, stormwater ponds were able to reduce the flooded volume and its hazard and damages. However, LIDs solutions were not able to completely eliminate floods in the region. Structural changes, as resizing the conduits into the drainage systems in the area, could improve the drainage system effectiveness avoiding floods and respective hazards and damages.
\end{abstract}

Keywords: SWMM; Sustainable techniques; Hazard analysis; Stormwater ponds; Permeable pavement.

\section{RESUMO}

O aumento da geração do volume do escoamento superficial irá ser um desafio aos futuros projetos de drenagem de urbana, e muitas estratégias sustentáveis podem ser efetivas no controle de inundações e no redesenho de áreas urbanas. Este estudo foca na avaliação das soluções de drenagem em áreas urbanas já consolidadas do Distrito Federal no Brasil, a fim de reduzir a vazão de pico, o volume inundado e as áreas sujeitas a perigo de inundação. Diferentes cenários foram simulados, e foi mostrado que o atual sistema de drenagem utilizado não está em conformidade com a regulamentação local. Além disso, o uso de pavimentos permeáveis com bacias de detenção poderiam reduzir em pelo menos $46 \%$ do volume inundado na região. Embora sejam responsáveis por uma significativa parcela na redução do perigo e do volume inundado, somente as LIDs não seriam suficientes por eliminar totalmente as inundações na região. Mudanças estruturais, como o redimensionamento dos condutos nos sistemas de drenagem, poderiam ajudar a anular completamente as inundações e os perigos.

Palavras-chave: SWMM; Técnicas sustentáveis; Análise de perigo; Bacias de detenção; Pavimentos permeáveis. 


\section{INTRODUCTION}

The increasing number of people living in urban areas and their high value economics activities are the most frequently affected during extreme rainfall events. The intensification of surface runoff due to increase of impervious surfaces in urban area expansion is causing unprecedented effects on drainage infrastructures and flooding events (MOURA; PELLEGRINO; MARTINS, 2016; VELASCO; CABELLO; RUSSO, 2016), creating a need for efficient, long-lasting and more sustainable drainage systems (SILLANPÄÄ; KOIVUSALO, 2015).

The greater intensity and frequency of rainfall events will pose a challenge to urban drainage design because they will have to deal with an increased frequency and volume of stormwater flows. Some solutions might not be attractive alternatives, such as expanding the underground drainage system, due to high costs in the long term (ZHOU et al., 2013). On the other hand, sustainable technologies that not only mitigate the problem but they also contribute to a more resilient urban area, such as low impact development practices - LIDs (MOURA; PELLEGRINO; MARTINS, 2016; FRENI; OLIVERI, 2005) rise as suitable alternatives to new designs of drainage system. These strategies have been the focus of several studies that tried to show that LIDs may be effective on flood control and retrofitting urban areas (AHIABLAME; ENGEL; CHAUBEY, 2013; AVILA; AVILA; SISA, 2016; HU et al., 2017; JACKISCH; WEILER, 2017).

These practices are based on local treatment, attenuation, reuse, retention, and infiltration of surface runoff promoting flood control whilst also contributing to aesthetics, social, and environmental values in the urban area (MOURA; PELLEGRINO; MARTINS, 2016). If carefully planned, a decentralized system can be part of green infrastructures in urban areas, also meeting demands for both climate change adaptation and urban recreational services (ZHOU et al., 2013).

The use of LIDs in new development areas is feasible, less expensive and involves fewer effects than retrofitting consolidated areas, considering that they do not require demolition costs or other costs related to relocating people or economic activities. For example, bioretention and porous pavements can ensure greater longevity for drainage infrastructure and avoid future investments in the implementation of stormwater ponds, however, both alternatives have caused challenges in maintenance and operation.

The performance of LIDs depends on the properties of each technique and the area chosen for implementation. For example, Hu et al. (2017) with pervious pavement application had better performance than rainwater harvesting as a retrofitting technology for flood inundation mitigation in the study watershed.

Another strategy that has been used to face flood events is the construction of stormwater ponds (CUNHA et al., 2016; TAO et al., 2014; KESSLER; DISKIN, 1991; PARK et al., 2014). These structures have been more widely used than others because their concepts are simple to apply (PARK et al., 2014). However, usually these reservoirs are built in large scale and at multiple points in the same watershed resulting in the reduction of their efficiency in decreasing peak flows over time, mainly because of the lack of maintenance (NASCIMENTO et al., 1999).

Since a wide variety of LIDs can be applied in an urbanized watershed, it is important to evaluate their effectiveness using hydrological modelling. For instance, Palla and Gnecco (2015) tested the effectiveness of green roofs and permeable pavements on peak flow reduction for different return periods. Avila, Avila and Sisa (2016) studied how spatially distributed stormwater ponds could attenuate flood risk.

The effectiveness of stormwater ponds and LIDs has been evaluated through many variables, such as, reduction of peak flow at the outlet of the watershed (AVILA; AVILA; SISA, 2016; CUNHA et al., 2016; PALLA; GNECCO, 2015); reduction of flooded volume resulting from an intense rainfall event (CUNHA et al., 2016; PALLA; GNECCO, 2015; TAO et al., 2014); measuring the number of rainfall events leading to flooding in different return time periods (AHIABLAME; SHAKYA, 2016); and assessing flood hazard and damage caused by intense rainfall events in a specific region (HU et al., 2017; RIBEIRO NETO; BATISTA; COUTINHO, 2016; VELASCO; CABELLO; RUSSO, 2016). Usually, flood hazard and damages are frequently associated with flood depths (ZHOU et al., 2013; VELASCO; CABELLO; RUSSO, 2016). In some cases, the flow velocity can also be an important variable because of its influence in losses of life and in structural building damage due to lateral pressure (STEPHENSON, 2002; MERZ et al., 2010).

The current study focused on the evaluation of drainage solutions to a consolidated urban area in the Federal District of Brazil. The research analysed the reduction of peak flow and flooded volume in areas exposed to flood hazard. A baseline scenario (existing conditions) was compared to scenarios of sustainable drainage alternatives. First, the efficiency of storage units at the outlet of the drainage network for the reduction of peak flow was tested. This alternative was followed by the implementation of permeable pavements and stormwater ponds along the network aiming to reduce the total flooded volume in the study area. Based on the simulated flooded volumes and on some predefined hazard index, the areas exposed to hazard were identified and a hazard map was defined for different scenarios (with and without LIDs). Finally, changes in the drainage network were proposed in order to reduce or eliminate the flood volumes in the areas exposed to flood hazard.

\section{METHODOLOGY}

In order to accomplish the objectives of this study, a simulation was developed using the Personal Computer Storm Water Management Model (PCSWMM) which is based on the USEPA Storm Water Management Model (SWMM, version 5) integrated into a Geographic Information System (GIS) (CHI WATER, 2017; ROSSMAN, 2015). The model has presented computational efficiency due to its simple structure and has been widely used for urban water and flood management (ROSSMAN, 2015; AHIABLAME; SHAKYA, 2016). It has been successfully tested in many studies in the Federal District of Brazil previously (COSTA; KOIDE, 2014; SILVA et al., 2017; BRANDÃO; COSTA; ALVES, 2019; SOUZA, COSTA; KOIDE, 2019; TSUJI; COSTA; KOIDE, 2019; CAMUZI et al., 2019). PCSWMM represents each sub-catchment as a nonlinear reservoir whose storage capacity is specified by a retention variable (ROSSMAN, 2015). The model implements flow routing methods, computes water balance using the SCS 
surface runoff method, and determines the discharge rate at the outlet using Manning's equation. The model can also simulate pollutant loads and LIDs practices. The study area, model inputs and modelling processes will be discussed in detail hereafter.

\section{Study area}

In the Federal District of Brazil, municipalities are defined as Administrative Region (AR). This work was done in part of the Ceilândia AR. The region, located in a Savanna area, went through a quick occupation and urban sprawl beginning in 1980 as a result of intense migration from other states of
Brazil to the Federal District. Between 1990 and 2000, more than 100,000 migrants arrived in the area (CODEPLAN, 2015). The drainage network system was built later in 1980. Since then, no other planning measures regarding the drainage system was developed in the area. Currently, the region suffers with yearly flash floods, reported by the population, local media and urban drainage institutions. This research focused in two urban sub-catchments of the Ceilândia Administrative Region (Figure 1): Sub-Catchment 1 (141 ha) and Sub-Catchment 2 (52 ha), with 30.14 and 34.85 minutes of time of concentration. The area, majorly residential, is comprised of 6,229 residences that shelter around 21,000 habitants (CODEPLAN, 2015).
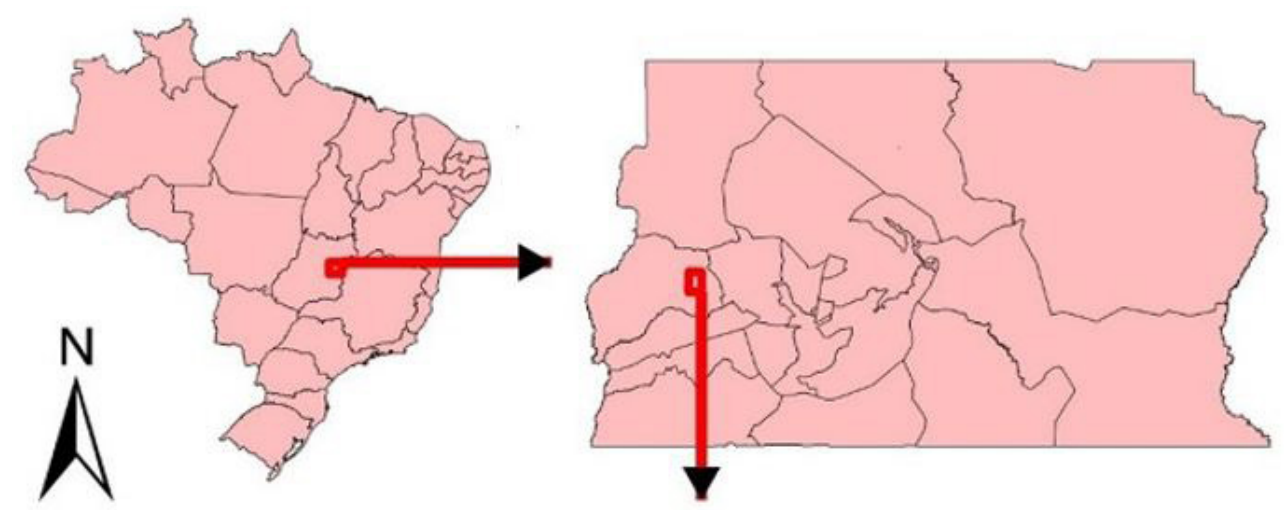

\section{Legend}

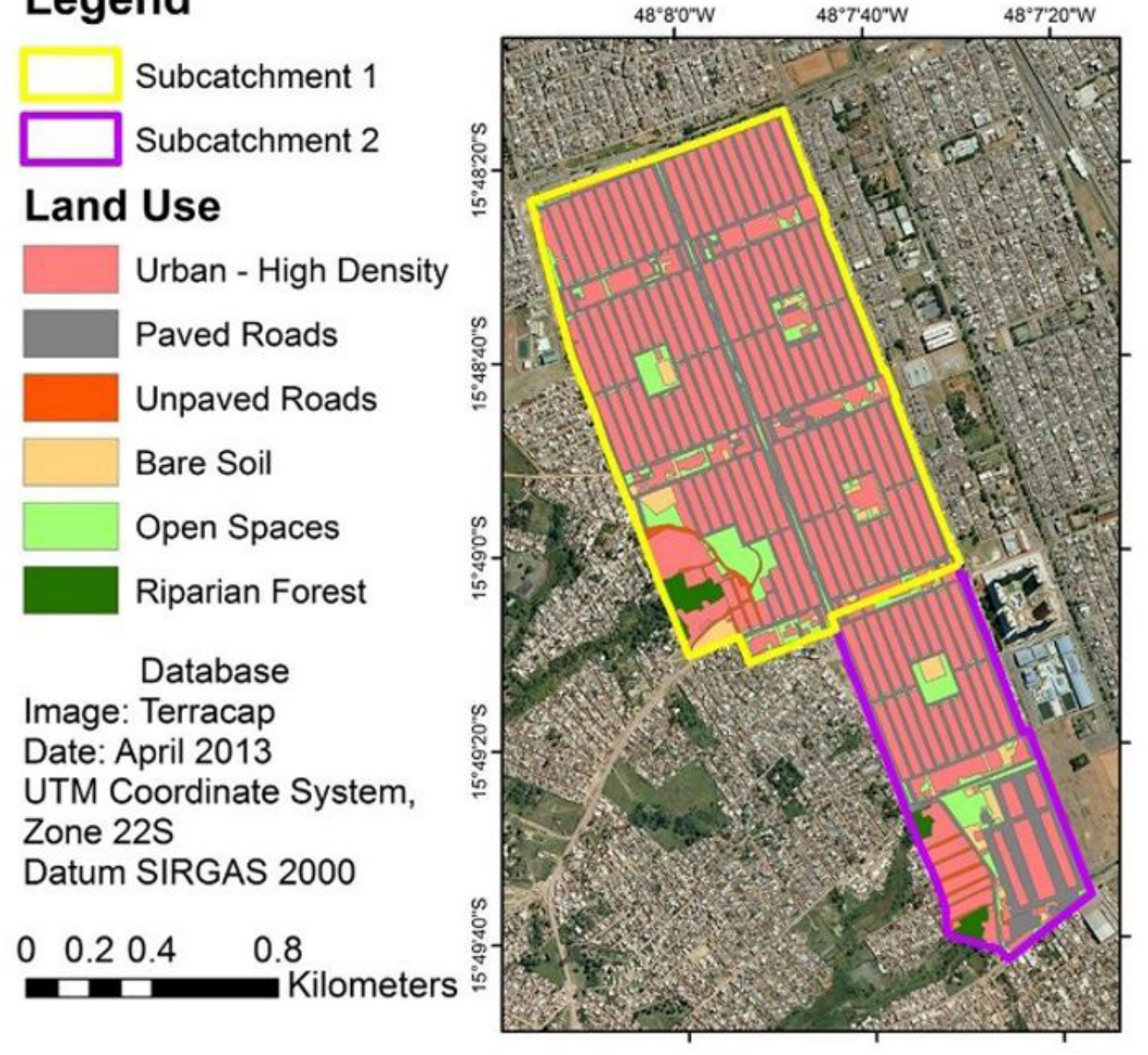

Figure 1. The Administrative Region of Ceilândia, in the Federal District of Brazil and its land use. 


\section{Model inputs}

The rainfall data were produced uniformly throughout the study area using Equation 1, defined by the Urban Drainage Master Plan of the Federal District. According to local regulations for new drainage system proposals (GOVERNO DO DISTRITO FEDERAL, 2009), single event precipitation with the return period of 10 years and rainfall duration of 24 hours was chosen. The 10 year return period was selected to verify the behaviour of the system conceived under the Federal District regulation, which is one of the objectives of this paper. Precipitation was discretized in five minutes interims, using alternating blocks methods.

$I=\frac{1574.70 * T_{r}^{0.207}}{(t+11)^{0.844}}$

Where, $\mathrm{I}$ is the intensity of precipitation $(\mathrm{mm} / \mathrm{h}), \mathrm{Tr}$ - return period (years), $\mathrm{t}$ - duration of precipitation (minutes).

Land use and soil type were used to characterise infiltration in the region. The SCS methodology was used to compute the infiltration, and consequently the excess runoff resulting from the synthetic rainfall.

Land use analysis was performed in six categories: Urban - High Density (57.5\%), Paved Roads (28.7\%), Unpaved Roads
(1.2\%), Bare Soil (2.8\%), Open Spaces (8.1\%) and Riparian Forest $(1.7 \%)$ as illustrated in Figure 1 and Table 1. High-density urban areas included residential and commercial areas, heavily impermeable areas, with $85 \%$ of its surfaces covered by roofing or concrete. Most roads in the region are paved with asphalt cover while a small percentage on the western part is still unpaved. Open spaces and bare soil were characterized as non-constructed urban spaces covered and uncovered by vegetation, respectively. There are also areas of dense vegetation in the western part of both sub-catchments, described as riparian forest. Furthermore, the region soil type is characterized by a high water infiltration rate and Hydrologic Soil Group (HSG) A.

The $\mathrm{CN}$ parameter varied between 25 to 98 , and the average $\mathrm{CN}$ of the region was 86 due to the high amount of impermeable surfaces such as paved roads (CN 98) and high-density urban areas (CN 88) (Table 1).

Aiming to identify areas exposed to flood hazard and define alternative solutions of sustainable drainage, the sub-catchment was discretized into smaller catchments according to the urban drainage network of the region, provided by The Construction Company of New Capital of Brazil (NOVACAP-DF). The network is a separate sewer drainage system, made of concrete, with the roughness of 0.017 . The system consists of 206 manholes and $12.3 \mathrm{~km}$ of conduits (Figure 2). A drainage area was associated

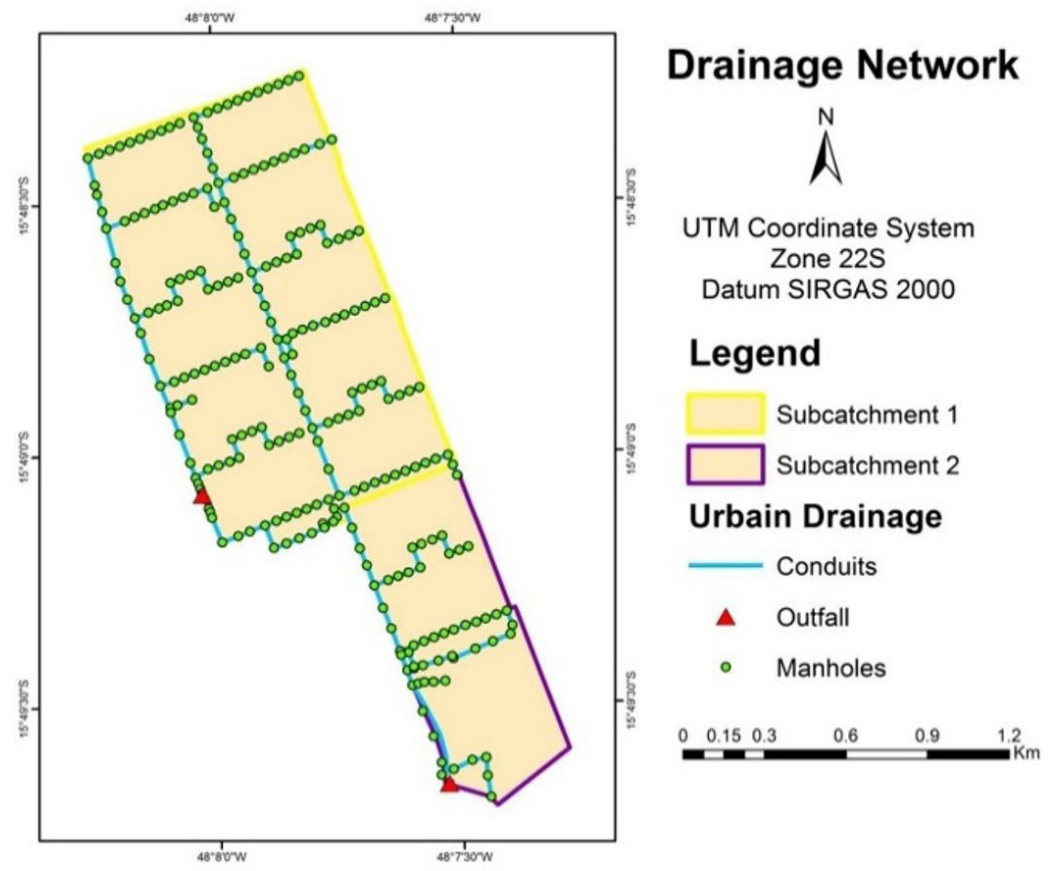

Figure 2. Drainage Network of the Study Area.

Table 1. Land Use and CN of the region.

\begin{tabular}{lcccc}
\hline \multicolumn{1}{c}{ Land Use } & Sub 1 (\%) & Sub 2 (\%) & Total Area (\%) & CN \\
\hline Urban - High Density & 60.0 & 50.7 & 57.5 & 88 \\
Paved Roads & 27.7 & 31.4 & 28.7 & 98 \\
Unpaved Roads & 1.0 & 1.8 & 1.2 & 72 \\
Bare Soil & 2.5 & 3.8 & 2.9 & 68 \\
Open Spaces & 7.5 & 9.6 & 8.1 & 49 \\
Riparian Forest & 1.3 & 2.7 & 1.7 & 25 \\
\hline
\end{tabular}


with each manhole using Voronoi Decomposition. Flow routing was done according to the direction of the flow in the conduits, from higher to lower elevation.

\section{$1 \mathrm{D}$ drainage network modelling}

Accurate model simulation of surface runoff in urban field-scale catchments $\left(<1 \mathrm{~km}^{2}\right)$ is of fundamental interest to the hydrologic community for practical and scientific reasons (ZHANG; SHUSTER, 2014), especially to evaluate the local flooding problems generated in those catchments and their resulting damages and costs. The impacts of urban floods can differ a lot from one street to the next one. Therefore, in terms of the spatial scale, assessments in urban areas clearly require a microscale study (VELASCO; CABELLO; RUSSO, 2016).

A dynamic wave routing simulation was performed to propose LIDs scenarios and to identify areas exposed to flood hazard in the study area. The procedure developed in this research allowed the evaluation of discharge, velocity and depth varying in time and space. The routing is done in the model using the Saint-Venant equations, ideal for the scenario presented, since the slope of the region is small and the impact of scour and deposition is negligible.

As a result of the absence of flow data in the field area, it was not possible to calibrate the model. But the study focused on comparing the efficiency of LIDs and stormwater ponds for the reduction of peak flow and flooded volume compared to a baseline scenario of "doing nothing" management and no LID infrastructure.

An important parameter used during the simulations is the ratio between width and length of each sub-catchment. This parameter influences the peak flow, associated with slope and the infiltration method. In order to estimate this parameter, the authors used the FLOW PATH function of the PCSWMM that calculate this attribute for each sub-catchments with the help of some GIS functions embedded.

\section{Scenarios studied}

The simulated scenarios included two LID strategies: stormwater ponds and porous pavements as retrofitting techniques for the study area. These alternatives were selected because of local regulation requirements, spatial availability and their efficiency in flood control (DREELIN; FOWLER; CARROLL, 2006; AHIABLAME; SHAKYA, 2016; AHIABLAME; ENGEL; CHAUBEY, 2013; CUNHA et al., 2016; HU et al., 2017).

Scenario 1 suggested the location of stormwater ponds at the network outfall in order to reduce peak flow to its level of natural state, according to local law which defines a maximum peak flow of $24.4 \mathrm{~L} / \mathrm{s} /$ ha for stormwater discharge in waterbodies (ADASA, 2011). In order to evaluate the benefits of LIDs on retrofitting areas (JACKISCH; WEILER, 2017), scenario 2 includes permeable pavements in addition to stormwater ponds. In scenario 3, stormwater ponds were also added along the network, since they may produce a positive impact on reduction of flooded areas (BELLU et al., 2016; CUNHA et al., 2016), additional to the two previous measures of scenario 2 . Those scenarios were compared to the current situation of the area, the baseline scenario, without any LID implemented (Table 2).

The storage volume of the stormwater ponds was calculated based on the percentage of impermeable area and the upstream discharge area, as stated by the regional guidelines (ADASA, 2011; Equation 2). The ponds located at the network outfall were preferably placed in public spaces (Table 3 and Figure 3). However, due to lack of space availability, the stormwater pond 1 was forcibly placed at some residential areas resulting in residence displacements. The siting of storage units along the network is the main strategy of scenario 3, which aims to reduce the upstream discharges without compromising space availability, being implemented where no population displacement was necessary.

$V=(4,705 x A i) A c$

Where, $\mathrm{V}$ is volume $\left(\mathrm{m}^{3}\right)$, Ai is impermeable area (\%), Ac is the contribution area (ha).

The porous pavement is comprised of two zones: a surface layer and a storage layer. The rainwater will be collected at the surface layer and part of the water will percolate into the storage zone. The excess water will overflow and generate surface runoff. The water collected at the storage zone will gradually infiltrate into the deeper layers of the soil in the sub-catchment. These processes are illustrated in Figure 4. There is no highway or heavily busy road inside the sub-catchments, therefore permeable pavement was implemented on the totality of roads of the sub-catchments, in scenarios 2 and 3. Porous pavements were designed according to the Brazilian Association of Technical Standards (ABNT NBR 16416)

Table 2. Description of the three scenarios evaluated.

\begin{tabular}{lcccc}
\hline \multicolumn{1}{c}{ LIDs Control } & Baseline Scenario & Scenario 1 & Scenario 2 & Scenario 3 \\
\hline Storage Unit - Outfall & $X$ & $\checkmark$ & $\checkmark$ & $\checkmark$ \\
Permeable Pavement & $X$ & $X$ & $\checkmark$ & $\checkmark$ \\
Storage Unit - Along Network & $X$ & $X$ & $X$ & $\checkmark$ \\
\hline
\end{tabular}

Table 3. Characteristic of the proposed stormwater pounds in corresponding scenarios.

\begin{tabular}{cccc}
\hline Storage & Area $\left(\mathrm{m}^{2}\right)$ & Scenarios proposed & Population Displacement \\
\hline 1 & 30,000 & Scenarios 1,2 and 3 & At least 50 houses \\
2 & 10,500 & Scenarios 1,2 and 3 & None \\
3 to 6 & 1,500 & Scenario 3 & None \\
7 & 2,000 & Scenario 3 & None \\
\hline
\end{tabular}



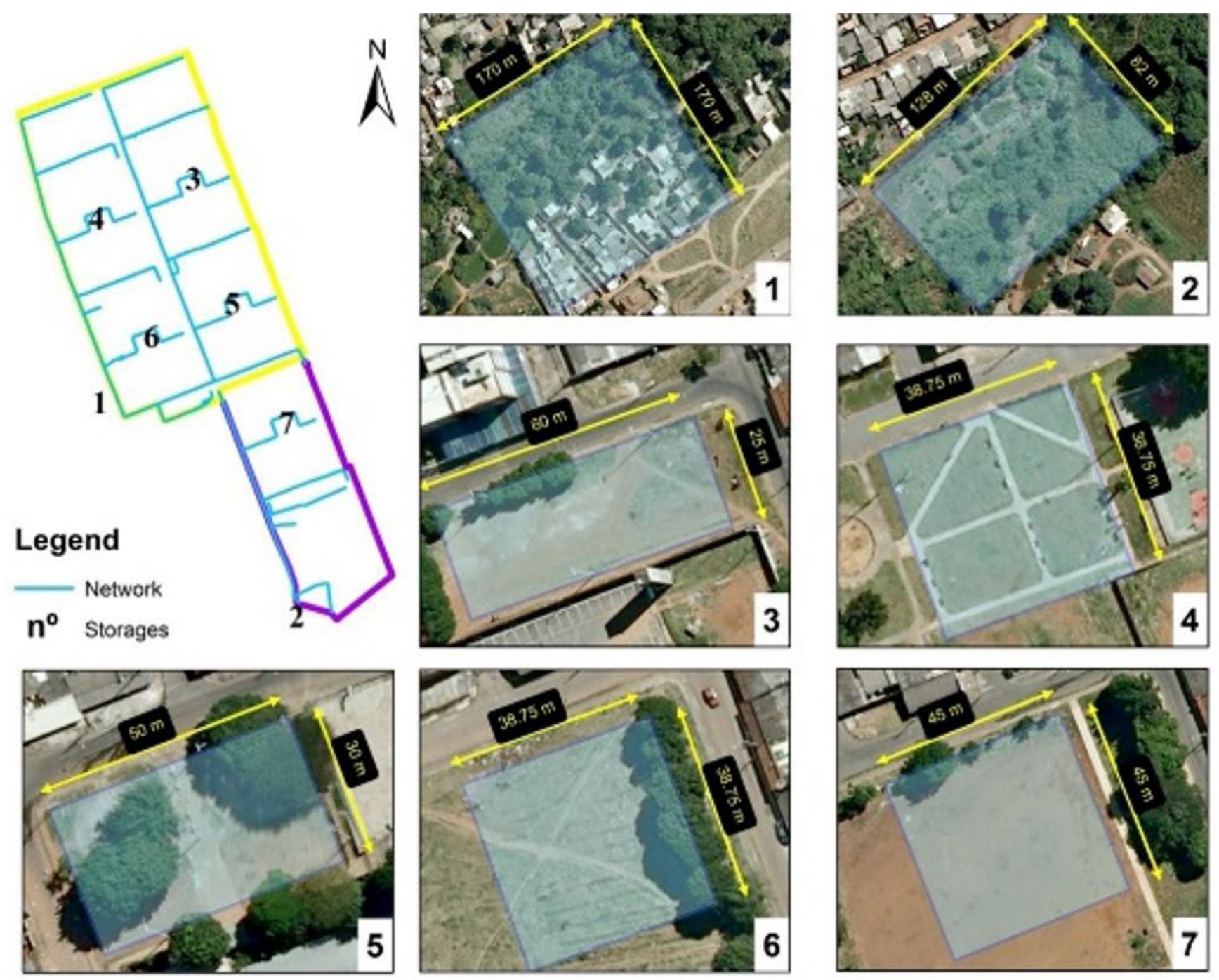

Figure 3. Location and dimensions of each proposed storage unit.

which requires a minimum permeability of $10^{-3} \mathrm{~m} / \mathrm{s}$ for porous pavement. Additionally, a thickness of $150 \mathrm{~mm}$ and void ratio (VR) of 0.75 for the pavement and a thickness of $300 \mathrm{~mm}$ and a void ratio of 0.21 for the porous layer were used (Figure 4).

\section{D flood modelling}

In order to better characterize the flood flow in selected hazardous areas, the $1 \mathrm{D}$ network model was integrated into a $2 \mathrm{D}$ module of PCSWMM. The method requires the spatial discretization of the catchment area into a hexagonal mesh of nodes. Herein a mesh resolution of $10 \mathrm{~m}$ was considered, as recommended by PCSWMM software (CHI WATER, 2017), given the average low slope of the terrain (less than $2 \%$ ). The nodes are connected with adjacent nodes by rectangular open channels, with length and width dependent on the distance between each node and area covered by the channel. A roughness of 0.02 was associated with the channels. The flow direction in the area is defined by the water surface elevation difference between the nodes, flowing from the higher head to the lower head node. In the present

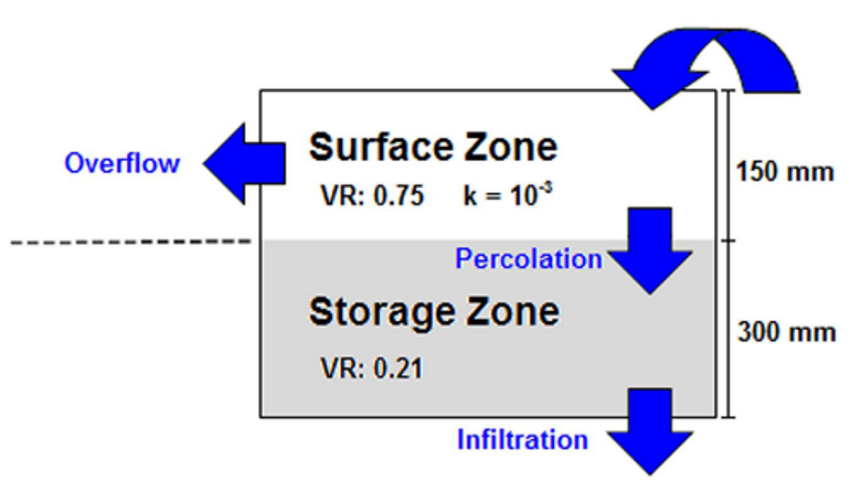

Figure 4. Permeable Pavement representation (ROSSMAN, 2016).

work, node elevation was defined with a $1 \mathrm{~m}$ resolution Digital Elevation Model (DEM) of the terrain. The PCSWMM then applies St-Venant Equations to each channel connection created in the process. The equations are solved using a finite difference approach with a method of successive approximations and under relaxation (CHI Water, 2017). The results were computed in time step of 0.5 seconds. 
The mesh created is then integrated with the $1 \mathrm{D}$ drainage network of the area. In the model, the excess discharge will flow out from the stormwater collection network, gradually flooding the created mesh. The $1 \mathrm{D}$ network and the $2 \mathrm{D}$ mesh were connected by manholes represented in the software by orifices. The manholes were placed matching the surface elevation of adjacent nodes, hence overflowing when they become pressurized.

Furthermore, to accurately represent the flood in the urban area an obstruction layer was introduced, representing building areas. The layer was manually constructed, following a high-resolution land use image of the area.

\section{Definition of areas exposed to flood hazard}

The 1D drainage network model shows the manholes that had overflowed. This information was used for the definition of the areas exposed to flood hazard in the catchments. Two areas that presented the greater number of overflown manholes and volume overflowed were selected for a detailed $2 \mathrm{D}$ investigation. The objective of the analysis is to characterise the potential hazard in those areas and measure the possible changes brought by the introduction of LIDs. A 2D simulation for the baseline scenario and scenario 3 was performed to see the possible improvements in the area. Those improvements were characterized by a flood hazard criteria defined by the authors.

The flood hazard criteria considered the water depth and velocity of each individual cell of the $2 \mathrm{D}$ model. Three levels of flood hazard were defined (Table 4) according to the thresholds of water depths and flow velocity. In this paper, Low Hazard represents the possible damages to vehicles on the roads but no damaged property is expected; Medium Hazard results in damage to properties in little extent and the water flowing in the streets have a higher hazard of damaging vehicles; and High Hazard: which represents more potential extensive damage to property, requiring cleaning and refurbishment works, furthermore the water flow may represent hazard to human lives and vehicle damages (STEPHENSON, 2002; MONTEIRO; KOBIYAMA, 2013; VELASCO; CABELLO; RUSSO, 2016; DROBOT; BENIGHT; GRUNTFEST, 2007).

\section{RESULTS}

Drainage network performance on the proposed scenarios

The maximum peak flow in the baseline scenario is greater than $24.4 \mathrm{~L} / \mathrm{s} /$ ha which is defined as the pre-development peak flow in the region (ADASA, 2011). Any of the proposed scenarios would reduce the peak flow in the outfall to an acceptable level (Figure 5).

The use of stormwater ponds at the outlet of the network (Scenario 1) resulted in the reduction of peak flow, by $86 \%$ and $84 \%$ on sub-catchments 1 and 2 respectively, and a slower discharge at the outfall (Figure 5 and Table 5). However, this scenario did not accomplish a reduction of the total volume drained to the outfall nor reduced the number and volume of manholes flooded (Table 5).

Table 4. Hazard Classification Criteria for RP 10 y.

\begin{tabular}{ll}
\hline \multicolumn{1}{c}{ Parameters } & \multicolumn{1}{c}{ Hazard } \\
\hline Depth: $0.02-0.15 \mathrm{~m}, \mathrm{~V} \geq 1 \mathrm{~m} / \mathrm{s}$ & Medium Hazard \\
Depth: $0.15-0.3 \mathrm{~m}$ and $\mathrm{V}<1 \mathrm{~m} / \mathrm{s}$ & High Hazard \\
Depth: $0.15-0.3 \mathrm{~m}$ and $\mathrm{V}>1 \mathrm{~m} / \mathrm{s}$ or Depth $>0.3 \mathrm{~m}$ & High \\
\hline
\end{tabular}
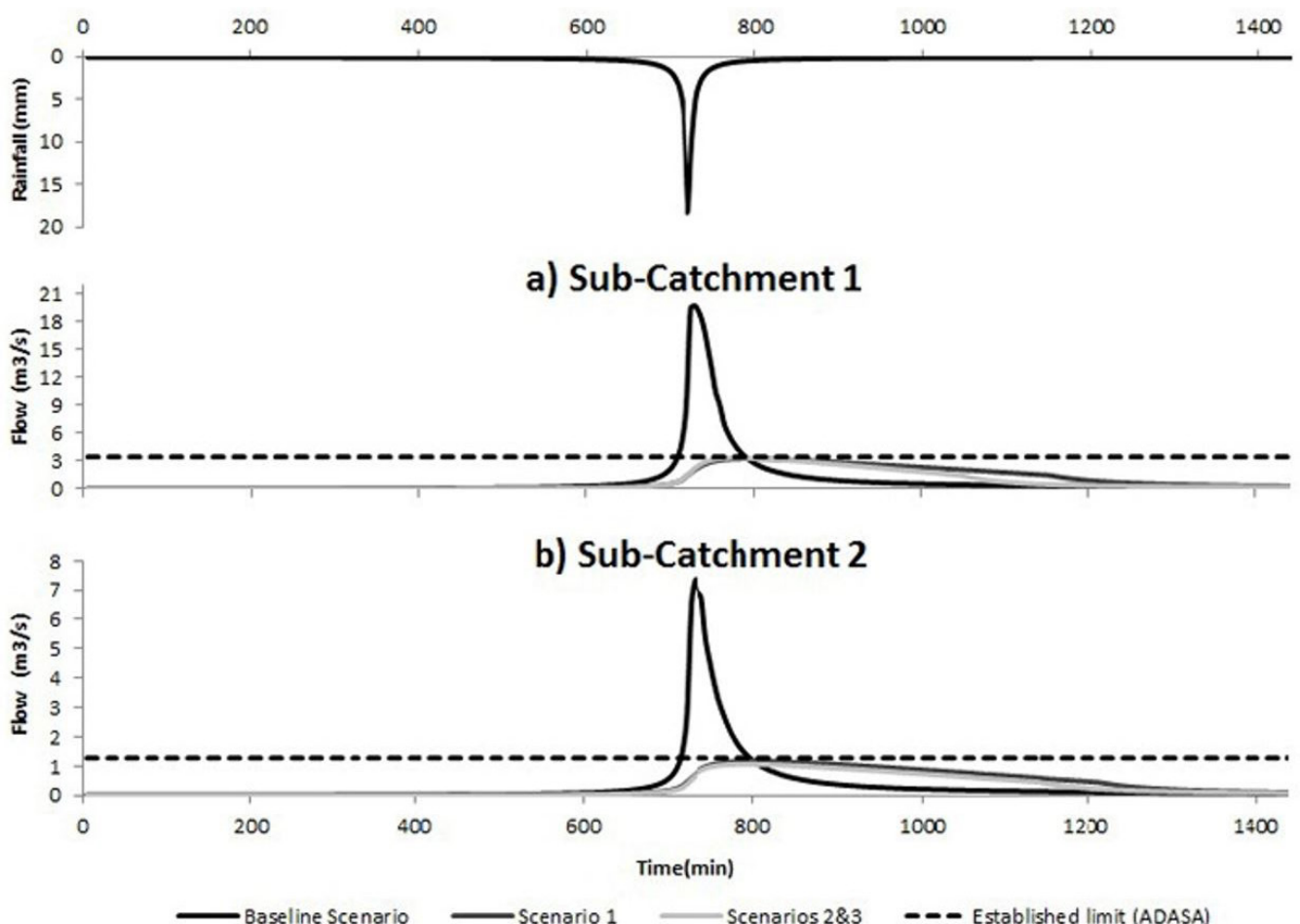

Figure 5. Rainfall distribution, hydrograph of each proposed scenario. 
Table 5. Results of each simulated scenario for the two sub-catchments studied.

\begin{tabular}{|c|c|c|c|c|c|c|c|}
\hline \multirow{2}{*}{ Parameters } & \multirow{2}{*}{$\begin{array}{l}\text { Baseline } \\
\text { Scenario }\end{array}$} & \multicolumn{2}{|c|}{ Scenario 1} & \multicolumn{2}{|c|}{ Scenario 2} & \multicolumn{2}{|c|}{ Scenario 3} \\
\hline & & Abs. Value & Red. $(\%)$ & Abs. Value & Red. $(\%)$ & Abs. Value & Red. $(\%)$ \\
\hline \multicolumn{8}{|l|}{ Sub-Catchment 1} \\
\hline Peak Flow $\left(\mathrm{m}^{3} / \mathrm{s}\right)$ & 19.7 & 3.25 & 86 & 3.42 & 83 & 3.42 & 83 \\
\hline Total Volume - Outfall $\left(\mathrm{m}^{3}\right)$ & 82,270 & 82,270 & - & 65,320 & 21 & 67,200 & 18 \\
\hline Flooded Volume $\left(\mathrm{m}^{3}\right)$ & 19,810 & 19,810 & - & 11,166 & 44 & 10,794 & 46 \\
\hline Flooded Manholes & 86 & 86 & - & 67 & 22 & 60 & 30 \\
\hline$\%$ Flooded Manholes & 46 & 46 & & 36 & & 32 & \\
\hline Time Flooded (min) & 59 & 59 & - & 47 & 21 & 47 & 21 \\
\hline \multicolumn{8}{|l|}{ Sub-Catchment 2} \\
\hline Peak Flow $\left(\mathrm{m}^{3} / \mathrm{s}\right)$ & 7.35 & 1.16 & 84 & 1.06 & 86 & 1.22 & 83 \\
\hline Total Volume - Outfall $\left(\mathrm{m}^{3}\right)$ & 30,490 & 30,500 & - & 25,120 & 17 & 24,480 & 20 \\
\hline Flooded Volume $\left(\mathrm{m}^{3}\right)$ & 4,554 & 4,579 & - & 2,737 & 40 & 2,342 & 49 \\
\hline Flooded Manholes & 18 & 18 & - & 13 & 28 & 11 & 39 \\
\hline \% Flooded Manholes & 31 & 31 & & 22 & & 19 & \\
\hline Time Flooded (min) & 45 & 45 & - & 37 & 19 & 37 & 19 \\
\hline
\end{tabular}

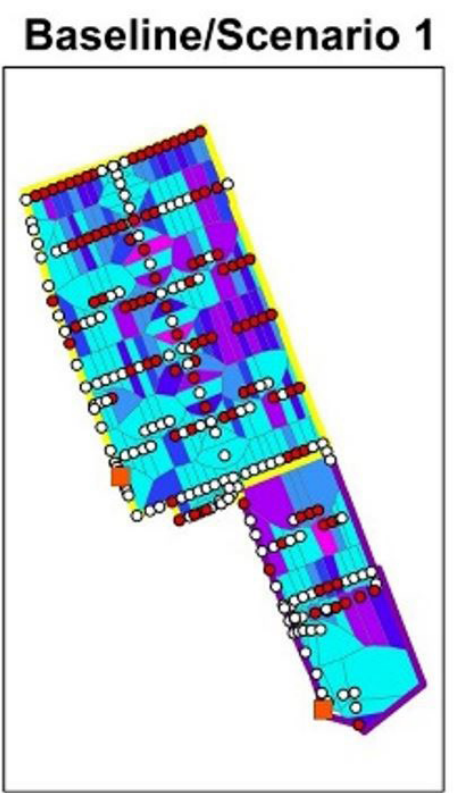

\section{Legend}

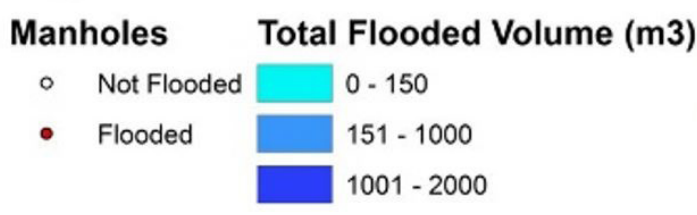

Scenario 2

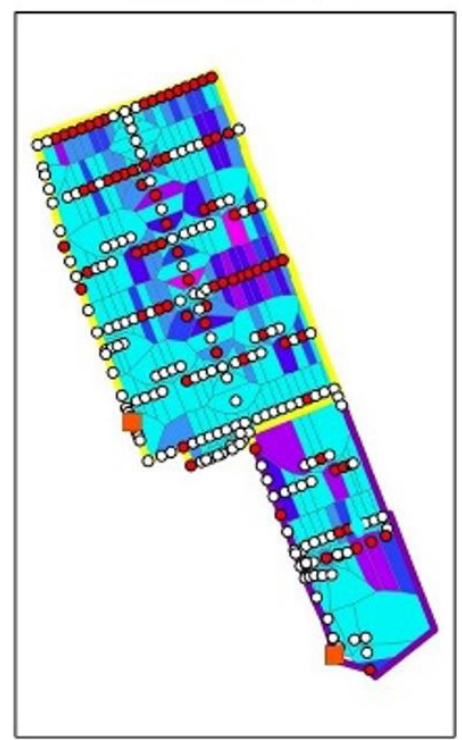

$2001-4000$

$4001-8000$

$8001-15000$
Scenario 3

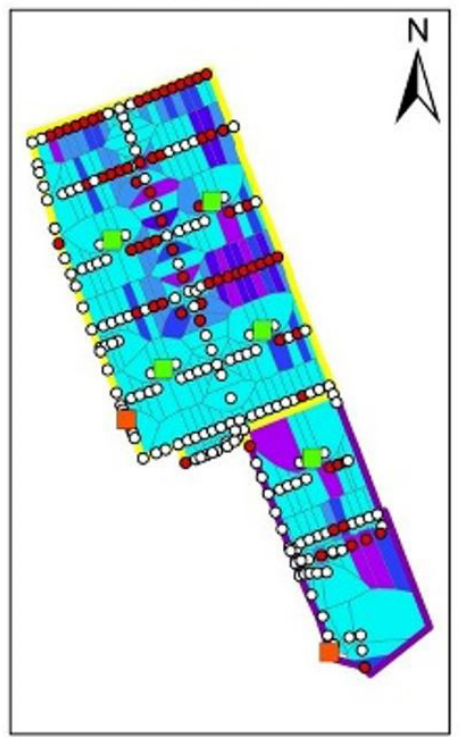

UTM Coordinate System

Zone 22S

DATUM SIRGAS 2000

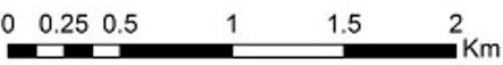

Figure 6. Total flooded volume on each sub-catchment division for each scenarios.

Permeable pavements coupled with stormwater ponds (Scenario 2) presented a similar reduction of peak flow than that of scenario 1 (83\% and $86 \%$ for sub-catchments 1 and 2 , respectively). In addition, the pavements were responsible for a $22 \%$ reduction of the volume drained to the outfall, a reduction of $22 \%$ in the number of manholes flooded and $40 \%$ of the total flooded volume (Table 5).

The stormwater ponds along the network (Scenario 3) would solve some specific network problems, located immediately downstream of the basins implemented. Peak flow attenuation was similar to the other scenarios. The reduction of total flooded volume and manholes flooded was more significant than those of scenario 2, with a total flooded volume reduction of at least $46 \%$ and the number of flooded manholes of at least $30 \%$.

The reduction of the number of manholes flooded in scenarios 2 and 3 is more expressive in the southern region of sub-catchment 1 ; and in the northern part of sub-catchment 2 (Figure 6). The total flooded volume also decreased in scenarios 2 and 3 . None of the sub-catchments presented flooded volume greater than $8,000 \mathrm{~m}^{3}$ and a reduction of the flooded volume on a large amount of sub-catchments divisions (Figure 6). 
Flooding evaluation on areas exposed to flood hazard s

On both sub-catchments, overall hazard has been reduced with the LIDs implementation; by $11.5 \%$ in 1 and by $8.9 \%$ in 2 . Compared to the base scenario, area 1 presented a more significant reduction of area in High Hazard, from $413 \mathrm{~m}^{2}$ to $140 \mathrm{~m}^{2}$, and Medium Hazard areas, from 2,907 $\mathrm{m}^{2}$ to $946 \mathrm{~m}^{2}$, with the use of LIDs. A reduction of Low Hazard areas also occurred on both areas, on a more significant scale in Area 2 where a reduction of 9.3\% occurred, compared to a 1.5\% reduction in Area 1 (Table 6).

The reduction of Medium and High Hazard of damaged areas on Area 1 occurred in two main roads of the neighbourhood, while reduction of Low Hazard occurred on secondary streets connecting residences to the road system (Figure 7). Only one point of Area 2 showed a reduction of High Hazard to Medium Hazard, and, most of the Low Hazard reduction occurred on secondary streets (Figure 7).

\section{DISCUSSION}

Effectiveness of LIDs and storages units on peak flow and flood volume reduction

Though the effectiveness of stormwater ponds can vary according to its shape design and maintenance (KESSLER; DISKIN, 1991; PARK et al., 2008), the use of large capacity ponds at the end of the network, in the study area, successfully reduced peak flow to local regulated level, accomplishing the objective of retrofitting.

However, as shown in scenario 1, the large capacity pond will not reduce flooding problems in some spots of the upstream drainage network, failing the concept of sustainable drainage (MARSALEK; SCHREIER, 2009).

However, the implementation of LIDs contributed to a reduction in the peak flow and flooded volume of an urban area. The results of scenario 2 showed that permeable pavements
Baseline Scenario

Area 1
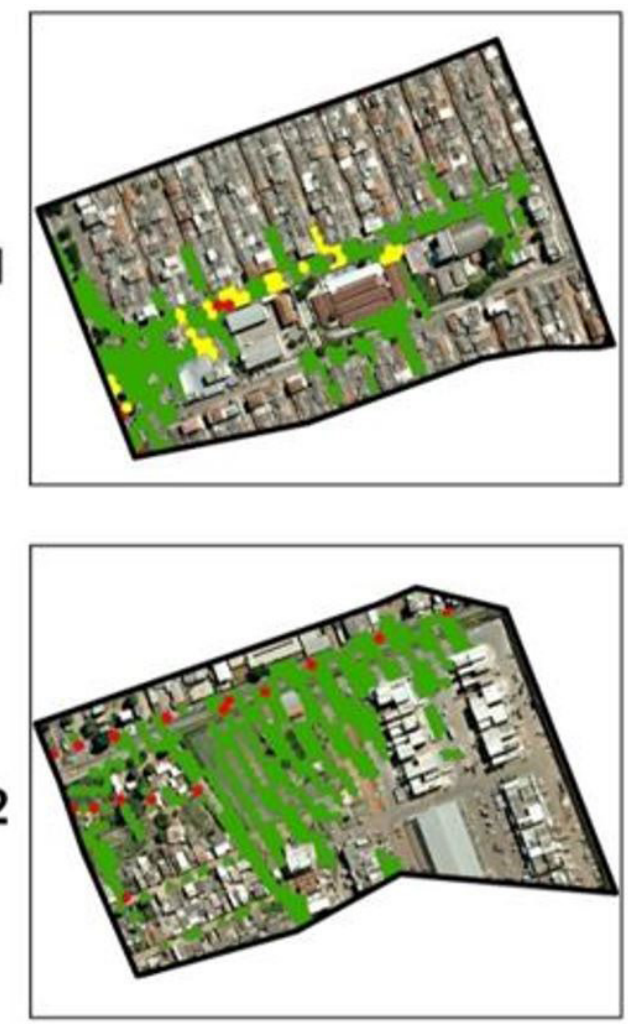

\section{Scenario 3}
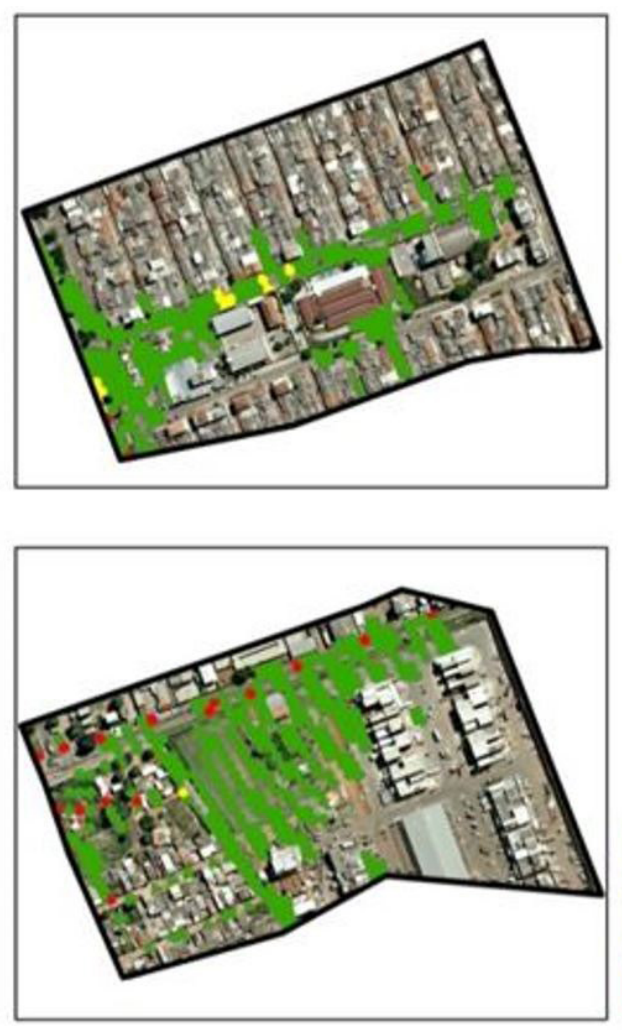

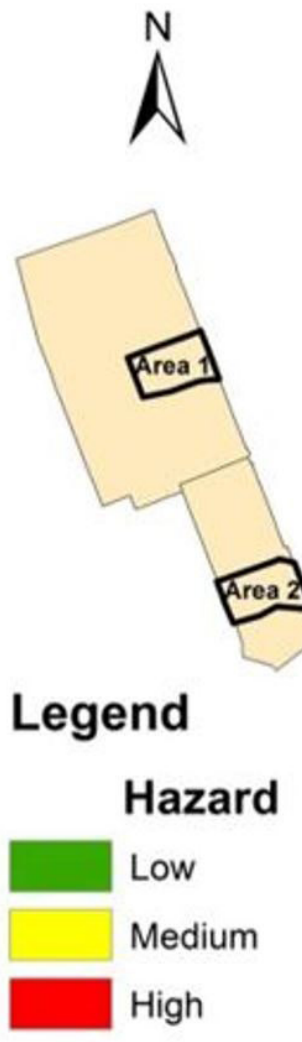

Figure 7. Distribution of hazard areas on hazardous areas 1 and 2.

Table 6. Reduction of areas exposed to flood hazard in scenario 3.

\begin{tabular}{|c|c|c|c|c|c|c|}
\hline \multirow{2}{*}{$\begin{array}{c}\text { Hazard of } \\
\text { Damage }\end{array}$} & \multicolumn{2}{|c|}{ Area $1\left(\mathrm{~m}^{2}\right)$} & \multirow{2}{*}{$\%$ Red. Area 1} & \multicolumn{2}{|c|}{ Area $2\left(\mathrm{~m}^{2}\right)$} & \multirow{2}{*}{$\%$ Red. Area 2} \\
\hline & Base & Scen. 3 & & Base & Scen. 3 & \\
\hline Low & 18,451 & 18,181 & 1.46 & 29,528 & 26,782 & 9.30 \\
\hline Medium & 2,907 & 946 & 67.46 & 0 & 87 & - \\
\hline High & 413 & 140 & 66.10 & 1,422 & 1,336 & 3.94 \\
\hline Overall & 21,770 & 19,267 & 11.50 & 30,950 & 28,205 & 8.87 \\
\hline
\end{tabular}


are responsible for a reduction of flooded volume $(>40 \%)$ and flooded manholes $(>22 \%)$ in a 10 -year flood event. Permeable pavements also reduced the runoff by 11 to $100 \%$ depending on the percentage of permeable pavements in the region, and watershed characteristics (AHIABLAME; SHAKYA, 2016; AHIABLAME; ENGEL; CHAUBEY, 2012), is considered the most beneficial retrofitting technology for flood attenuation (CHUI; LIU; ZHAN, 2016; HU et al., 2017). Furthermore, if the alternative solution is coupled with other LIDs technologies they can be more effective (AHIABLAME; SHAKYA, 2016; VASCONCELOS; MIGUEZ; VAZQUEZ, 2016).

As presented in Scenario 3, the use of stormwater ponds along the drainage network can be an effective solution for the attenuation of flood volume in specific locations. The allocation of those units is of extreme importance in the results. Cunha et al. (2016) showed that the reduction of flood volume in a watershed can vary from $41 \%$ to $90 \%$ according to location and number of built units. In scenario 3 , the site selection of stormwater ponds was limited by the constraint of not allowing additional structural change other than the construction of the pond itself. If other structural changes were considered (such as the removal of population or road displacements), better results could have been achieved.

\section{Areas exposed to flood hazard and expected damage}

From the simulations, we can conclude that the current drainage system is undersized. Although floods in the area could cause a low life-threatening hazard to the population, it could cause significant damage in infrastructure and could disrupt traffic in the region.

The use of sustainable drainage reduced the magnitude of hazard, thus reducing floods costs and inconvenience. However, given the critical situation of the area, structural solutions are required, such as pipe enlargement or construction of underground reservoirs.

\section{Limitation of the study}

The absence of flow data and calibration may introduce significant uncertainties to the model. However, it has been showed that the SWMM model can produce relatively accurate results even when there is a lack of data to calibrate the model (ZHANG; SHUSTER, 2014).

Also, the mesh discretization, size, and resolution of the 2D model could be improved. Moreover, the obstruction layer was manually constructed, however, building areas should be represented by a single layer unavailable at the time of building the model for the study area.

Some instabilities of the model in the places could be observed into nodes, where it was represented with high hazard probably because of the coupling of $1 \mathrm{D}$ with $2 \mathrm{D}$ model in the PCSWMM software.

Despite the increasing number of studies on LIDs, its efficiency is still uncertain. Simulations show a great range when analysing the effectiveness of LIDs on flood event control
(AHIABLAME; SHAKYA, 2016; AHIABLAME; ENGEL; CHAUBEY, 2012; AVILA; AVILA; SISA, 2016; FRENI; OLIVERI, 2005; MOURA; PELLEGRINO; MARTINS, 2016). However, the LIDs practices remain the more reliable path to improve the protection of the urban watershed, reduction of loss of urban ecosystem value and human life and property protection.

It is important that in the Savanna region, as Federal District, the climate is very particular with two well-defined climatic seasons: rainy and dry. Therefore, LIDs such as private reservoirs or green roof may not be as effective. The first one, because of the size, that it is necessary big reservoirs to supply some house during the dry period. The second one, because the need for irrigation during the dry period, which where costs can make the project unfeasible. Also, in Savanna region, there is a predominance of the latosol, a type of soil with great infiltration capacity as a type of vegetation that provides the retention by the soil, because of that, permeable pavements are considered for the area. However, the large rate of imperviousness in urban areas does not allow the interaction of rainfall with the soil, generating a greater amount of surface runoff.

\section{CONCLUSIONS}

This work presented an evaluation of alternative solutions for sustainable drainage system in a consolidated urban area in the Federal District of Brazil in terms of peak flow discharge and flooded volumes. The PCSWMM model was applied to simulate the LIDs solutions. The authors concluded that:

(1) The current area of Ceilândia AR presents serious drainage infrastructural problems. The drainage system is not in compliance with current local regulation. It was not able to manage precipitation of 24 hours for a 10 years return period, causing damage and inconvenience to the population and environment;

(2) The implementation of stormwater ponds at the end of the network to reduced peak flow to its natural state and complied with the Federal District regulations. However, the ponds did not avoid flooding upstream in events of intense precipitations what could result in economic and social damages in the area;

(3) The use of permeable pavements reduced more than $40 \%$ of the total flooded volume in the region, reducing the number of areas subject to flood by $11.5 \%$ and $8.9 \%$ in two areas most exposed to flood hazard in the study area;

(4) Stormwater ponds placed along the drainage network solved part of the problems. The combination of permeable pavements and those pond units could reduce the total volume flooded by a bigger extent than using solely pavements. Results showed a reduction of at least $46 \%$ of the flooded volume in this scenario;

(5) Although responsible for a significant reduction of hazard and flooded volume, floods will still occur in the region. A more significant reduction could have been achieved if structural changes in the area were considered, such as changing part of the network system diameter. 


\section{ACKNOWLEDGEMENTS}

The authors would like to express gratitude to ADASA and NOVACAP for most of the data of the drainage network system and also to the PCSWMM model team for allowing the academic license of the software.

\section{REFERENCES}

ADASA - AGÊNCIA REGULADORA DE ÁGUAS ENERGIA E SANEAMENTO DO DISTRITO FEDERAL. Resolução n ${ }^{\circ}$ 09, de 08 de abril de 2011. Diário Oficial [da] República Federativa do Brasil, Brasília, DF, 08 abr. 2011.

AHIABLAME, L. M.; ENGEL, B. A.; CHAUBEY, I. Effectiveness of low impact development practices: literature review and suggestions for future research. Water, Air, and Soil Pollution, v. 223, n. 7, p. 4253-4273, 2012. http://dx.doi.org/10.1007/s11270-012-1189-2.

AHIABLAME, L. M.; ENGEL, B. A.; CHAUBEY, I. Effectiveness of low impact development practices in two urbanized watersheds: Retro fitting with rain barrel / cistern and porous pavement. Journal of Environmental Management, v. 119, p. 151-161, 2013. http://dx.doi. org/10.1016/j.jenvman.2013.01.019. PMid:23474339.

AHIABLAME, L.; SHAKYA, R. Modeling flood reduction effects of low impact development at a watershed scale. Journal of Environmental Management, v. 171, p. 81-91, 2016. http:/ /dx.doi. org/10.1016/j.jenvman.2016.01.036. PMid:26878221.

AVILA, H.; AVILA, L.; SISA, A. Dispersed storage as stormwater runoff control in consolidated urban watersheds with flash flood risk. Journal of Water Resources Planning and Management, v. 142, n. 12, p. 4016056, 2016. http://dx.doi.org/10.1061/(ASCE)WR.19435452.0000702 .

BELLU, A.; SANCHES FERNANDES, L. F.; CORTES, R. M. V.; PACHECO, F. A. L. A framework model for the dimensioning and allocation of a detention basin system: The case of a flood-prone mountainous watershed. Journal of Hydrology, v. 533, p. 567-580, 2016. http://dx.doi.org/10.1016/j.jhydrol.2015.12.043.

BRANDÃO, T. J.; COSTA, M. E. L.; ALVES, C. M. A. Modelling urban drainage in taquari - federal district in brazil. In: MANNINA, G. (Ed.) New trends in urban drainage modelling - green energy and technology. Cham: Springer, 2019. p. 550-554.

CAMUZI, V.M.; COSTA,M.E.L.; SCHLEICHER, A.T.; COSTA, J.; KOIDE, S. Modelling study on the impacts of BMPs at Riacho Fundo (Brasília, Brazil). In: MANNINA, G. (Ed.) New trends in urban drainage modelling - green energy and technology. Cham: Springer, 2019. p. 120-125.

CHUI, T. F. M.; LIU, X.; ZHAN, W. Assessing cost-effectiveness of specific LID practice designs in response to large storm events. Journal of Hydrology, v. 533, p. 353-364, 2016. http://dx.doi. org/10.1016/j.jhydrol.2015.12.011.
COMPANHIA DE PLANEJAMENTO DO DISTRITO FEDERAL - CODEPLAN. Pesquisa Distrital por Amostra de Domicílios - PDAD - Ceilândia. Brasília: CODEPLAN, 2015.

COSTA, M. E. L.; KOIDE, S. Monitoring and modeling of the urban water drainage basin of lake Paranoá. In: INTERNATIONAL CONFERENCE ON URBAN DRAINAGE, 13., 2014 September 7-12, Sarawak, Malaysia. Proceedings... Kuala Lumpur: Ministry of Natural Resources and Environment Malaysia, 2014. p. 1-8.

CUNHA, M. C.; ZEFERINO, J. A.; SIMÕES, N. E.; SALDARRIAGA, J. G. Optimal location and sizing of storage units in a drainage system. Environmental Modelling \& Software, v. 83, p. 155-166, 2016. http://dx.doi.org/10.1016/j.envsoft.2016.05.015.

DREELIN, E. A.; FOWLER, L.; CARROLL, C. R. A test of porous pavement effectiveness on clay soils during natural storm events. Water Research, v. 40, n. 4, p. 799-805, 2006. http://dx.doi. org/10.1016/j.watres.2005.12.002. PMid:16426659.

DROBOT, S. D.; BENIGHT, C.; GRUNTFEST, E. C. Risk factors for driving into flooded roads. Environmental Hazards, v. 7, n. 3, p. 227-234, 2007. http://dx.doi.org/10.1016/j.envhaz.2007.07.003.

FRENI, G.; OLIVERI, E. Mitigation of urban flooding: a simplified approach for distributed stormwater management practices selection and planning. Urban Water Journal, v. 2, n. 4, p. 215-226, 2005. http://dx.doi.org/10.1080/15730620500386461.

GOVERNO DO DISTRITO FEDERAL. Plano diretor de drenagem urbana. Distrito Federal, 2009. v. 2.

HU, M.; SAYAMA, T.; ZHANG, X.; TANAKA, K.; TAKARA, K.; YANG, H. Evaluation of low impact development approach for mitigating flood inundation at a watershed scale in China. Journal of Environmental Management, v. 193, p. 430-438, 2017. http://dx.doi. org/10.1016/j.jenvman.2017.02.020. PMid:28237222.

JACKISCH, N.; WEILER, M. The hydrologic outcome of a Low Impact Development (LID) site including superposition with streamflow peaks. Urban Water Journal, v. 14, n. 2, p. 143-159, 2017. http://dx.doi.org/10.1080/1573062X.2015.1080735.

KESSLER, A.; DISKIN, M. H. The efficiency function of detention reservoirs in urban drainage systems. Water Resources Research, v. 27, n. 3, p. 253-258, 1991. http://dx.doi.org/10.1029/90WR02143.

MARSALEK, J.; SCHREIER, H. Innovation in Stormwater Management in Canada: The Way Forward. Water Quality Research Journal of Canada, v. 44, n. 1, p. V-X, 2009. http://dx.doi. org/10.2166/wqri.2009.001.

MERZ, B.; HALL, J.; DISSE, M.; SCHUMANN, A. Fluvial flood risk management in a changing world. Natural Hazards and Earth System Sciences, v. 10, n. 3, p. 509-527, 2010. http://dx.doi. org/10.5194/nhess-10-509-2010.

MONTEIRO, L. R.; KOBIYAMA, M. Proposta de metodologia de mapemaento de perigo de inundação. REGA, v. 10, n. 2, p. 13-25, 2013. http://dx.doi.org/10.21168/rega.v10n2.p13-25. 
MOURA, N. C. B.; PELLEGRINO, P. R. M.; MARTINS, J. R. S. Best management practices as an alternative for flood and urban storm water control in a changing climate. Journal of Flood Risk Management, v. 9, n. 3, p. 243-254, 2016. http://dx.doi.org/10.1111/ jfr3.12194.

NASCIMENTO, N. O.; ELLIS, J. B.; BAPTISTA, M. B.; DEUTSCH, J.-C. Using detention basins: operational experience and lessons. Urban Water, v. 1, n. 2, p. 113-124, 1999. http://dx.doi.org/10.1016/ S1462-0758(00)00009-1.

PALLA, A.; GNECCO, I. Hydrologic modeling of low impact development systems at the urban catchment scale. Journal of Hydrology, v. 528, p. 361-368, 2015. http://dx.doi.org/10.1016/j. jhydrol.2015.06.050.

PARK, D.; JANG, S.; ROESNER, L. A. Evaluation of multiuse stormwater detention basins for improved urban watershed management. Hydrological Processes, v. 28, n. 3, p. 1104-1113, 2014. http://dx.doi.org/10.1002/hyp.9658.

PARK, S. Y.; LEE, K. W.; PARK, I. H.; HA, S. R. Effect of the aggregation level of surface runoff fields and sewer network for a SWMM simulation. Desalination, v. 226, n. 1-3, p. 328-337, 2008. http://dx.doi.org/10.1016/j.desal.2007.02.115.

RIBEIRO NETO, A.; BATISTA, L. F. D. R.; COUTINHO, R. Q. Methodologies for generation of hazard indicator maps and flood prone areas: municipality of Ipojuca/PE. Revista Brasileira de Recursos Hídricos, v. 21, n. 2, p. 377-390, 2016. http://dx.doi. org/10.21168/rbrh.v21n2.p377-390.

ROSSMAN, L. A. Storm water management model reference manual. Washington: Environmental Protection Agency (EPA), 2015. (Volume I - Hydrology).

ROSSMAN, L. A. Stormwater management model reference manual. Washington: Environmental Protection Agency (EPA), 2016. (Volume III - Water Quality).

SILLANPÄÄ, N.; KOIVUSALO, H. Impacts of urban development on runoff event characteristics and unit hydrographs across warm and cold seasons in high latitudes. Journal of Hydrology (Amsterdam), v. 521, p. 328-340, 2015. http://dx.doi.org/10.1016/j. jhydrol.2014.12.008.

SILVA, E. C. B.; COSTA, M. E. L.; SILVA, C. C.; KOIDE, S. Analysis of the urbanization evolution effect on runoff using SWMM and ABC models. In: INTERNATIONAL CONFERENCE ON URBAN DRAINAGE, 14., 2017 September 10-15, Prague, Czech Republic, Proceedings... Prague: ICUD, 2017. Available from: $<$ https://www.researchgate.net/publication/320012201_Analysis_ of_the_urbanization_evolution_effect_on_runoff_using_SWMM_ and_ABC_models>. Access on: 6 jan. 2018.

SOUZA, F.P.; COSTA, M.E.L.; KOIDE, S. Hydrological modelling and detention ponds evaluation at Paranoa lake - Brazil. In: MANNINA, G. (Ed.) New trends in urban drainage modelling - green energy and technology. Cham: Springer, 2019. p. 649-653.
STEPHENSON, D. Integrated flood plain management strategy for the Vaal. Urban Water, v. 4, n. 4, p. 423-428, 2002. http:/ /dx.doi. org/10.1016/S1462-0758(02)00032-8.

TAO, T.; WANG, J.; XIN, K.; LI, S. Multi-objective optimal layout of distributed storm-water detention. International Journal of Environmental Science and Technology, v. 11, n. 5, p. 1473-1480, 2014. http://dx.doi.org/10.1007/s13762-013-0330-0.

TSUJI, T. M.; COSTA, M. E. L.; KOIDE, K. Urban stormwater monitoring and modelling at the Riacho Fundo Sub-Basin, Brasília - DF. In: MANNINA, G. (Ed.) New trends in urban drainage modelling - green energy and technology. Weinheim: Springer, 2019. p. 407-412.

VASCONCELOS, A. F.; MIGUEZ, M. G.; VAZQUEZ, E. G. Critérios de projeto e benefícios esperados da implantação de técnicas compensatórias em drenagem urbana para controle de escoamentos na fonte, com base em modelagem computacional aplicada a um estudo de caso na zona oeste do Rio de Janeiro. Engenharia Sanitaria e Ambiental, v. 21, n. 4, p. 655-662, 2016. http:/ / dx.doi.org/10.1590/s1413-41522016146469.

VELASCO, M.; CABELLO, À.; RUSSO, B. Flood damage assessment in urban areas. Application to the Raval district of Barcelona using synthetic depth damage curves. Urban Water Journal, v. 13, n. 4, p. 426-440, 2016. http://dx.doi.org/10.1080/ 1573062X.2014.994005.

CHI WATER. PCSWMM support. Ontario: CHI Water, 2017. Available from: <https://support.chiwater.com/>. Access on: 6 jan. 2017.

ZHANG, Y.; SHUSTER, W. The comparative accuracy of two hydrologic models in simulating warm-season runoff for two small, hillslope catchments. Journal of the American Water Resources Association, v. 50, n. 2, p. 434-447, 2014. http://dx.doi.org/10.1111/ jawr.12135.

ZHOU, Q.; PANDURO, T. E.; THORSEN, B. J.; ARNBJERGNIELSEN, K. Adaption to extreme rainfall with open urban drainage system: An integrated hydrological cost-benefit analysis. Environmental Management, v. 51, n. 3, p. 586-601, 2013. http:// dx.doi.org/10.1007/s00267-012-0010-8. PMid:23334752.

\section{Authors contributions}

Felipe de Mendonça Fileni: Author of the research that resulted in this article. Participated in all stages: bibliographic review, collection, processing and analysis of the data and writing of the article.

Maria Elisa Leite Costa: Ph.D. student of the same research line and co-supervisor of this research. Responsible for guiding the author with the model, data processing and writing of the article.

Conceição de Maria Alves Albuquerque: Supervisor of the research that resulted in this article. Responsible for the guidance of the author and the applied methodology. 